\title{
Bovine herpesvirus type 5 (BHV-5) in a calf with rabies 1
}

\author{
Fernando R. Spilki ${ }^{3}$, Ana C. Franco ${ }^{3}$, Marjorie B. Teixeira ${ }^{3}$, Paulo A. Esteves ${ }^{3}$, Rejane \\ Schaefer ${ }^{3}$, Eduardo Schmidt ${ }^{2}$, Ricardo A. Lemos ${ }^{4}$ and Paulo M. Roehe ${ }^{2,3, *}$
}

\begin{abstract}
Spilki F.R., Franco A.C., Teixeira M.B., Esteves P.A., Schaefer R., Schmidt E., Lemos R.A. \& Roehe P.M. 2003. Bovine herpesvirus type 5 (BHV-5) in a calf with rabies. Pesquisa Veterinária Brasileira 23(1):1-4. Centro de Pesquisas Veterinárias Desidério Finamor, FepagroSaúde Animal, Cx. Postal 2076, Porto Alegre, RS 90001-970, Brazil.

The brain of an one year old male calf which died with signs of neurological disease was submitted to the laboratory for rabies diagnosis. Microscopical findings included moderate mielitis, mild meningoencephalitis with perivascular cell cuffing and Negri inclusion bodies in Purkinje cells of the cerebellum. Rabies virus infection was further confirmed by the direct fluorescent antibody test as well as by mouse inoculation. In addition, a herpesvirus was isolated from brain tissues. The isolate was antigenic and genetically characterized as bovine herpesvirus type 5 (BHV-5). It was not possible to determine whether BHV-5 played an active role in the outcome of the infection, since, the virus might have been present in a latent form in neural tissues. This is the first report of a mixed rabies/ BHV-5 infection in calves.
\end{abstract}

INDEX TERMS: Bovine herpesvirus type 5, BHV-5, rabies.

RESUMO.- [Herpesvírus bovino tipo 5 (BHV-5) em bovino infectado pelo vírus da raiva. I 0 encéfalo de um bezerro macho, de um ano de idade, que morreu com sinais de doença neurológica, foi submetido ao laboratório para diagnóstico de raiva. $\mathrm{O}$ exame histopatológico revelou mielite moderada, meningoencefalite leve com infiltração perivascular e corpúsculos de Negri nas células de Purkinje do cerebelo. A infecção pelo vírus rábico foi ainda confirmada por imunofluorescência direta e por inoculação em camundongos. Além disso, um herpesvírus foi isolado dos tecidos do encéfalo. $O$ vírus isolado foi antigênica e geneticamente caracterizado como Herpesvírus bovino tipo 5 (BHV-5). Não foi possível determinar se o BHV-5 teve algum papel ativo no desfecho da enfermidade, uma vez que o vírus poderia estar presente

\footnotetext{
${ }^{1}$ Accepted for publication on November 14, 2002.

${ }^{2}$ Departamento de Microbiologia, Laboratório de Virologia, Universidade Federal do Rio Grande do Sul (UFRGS), Porto Alegre, RS 90050-170, Brasil.

${ }^{3}$ Equipe de Virologia, Fepagro-Saúde Animal, Centro de Pesquisas Veterinárias Desidério Finamor (CPVDF), Estrada do Conde 6000, Eldorado do Sul, RS 90001-970. "Autor para correspondência: Caixa Postal 2076, Porto Alegre, RS 90001-970, Brasil. Email: proehe@vortex.ufrgs.br

${ }^{4}$ Universidade Federal de Mato Grosso do Sul (UFMS), Campo Grande, MS 79070-900.
}

em forma latente nos tecidos neurais. Este é o primeiro relato de uma infecção mista pelo vírus da raiva e BHV-5 em bovinos.

TERMOS DE INDEXAÇÃO: Herpesvírus bovino tipo 5, BHV-5, raiva.

\section{INTRODUCTION}

Rabies is the most prevalent cause of central nervous system (CNS) disease in cattle in southern Brazil (Sanches et al. 2000). Routine rabies laboratory diagnosis is based on direct fluorescent antibody testing (DFAT) and mouse inoculation (Murphy et al. 1999). Due to the nature of the disease and its invariably fatal outcome, when rabies virus is identified, no other agents are routinely searched for. In view of that, mixed infections with rabies virus and other agents are not reported.

On the other hand, bovine herpesvirus type 5 (BHV-5), a member of the family Herpesviridae, subfamily Alphaherpesvirinae, is the causative agent of bovine herpesvirus encephalitis (French 1962, Johnston \& McGavin 1962, Gardiner \& Nairn 1964, Murphy et al. 1999). This virus has recently been shown to be the second major identified cause of lethal encephalitis in cattle (Sanches et al. 2000). In Brazil, the number of documented cases of BHV-5 encephalitis is increasing steadily, particularly in the regions 
of the Pantanal (Southern Amazon), the Amazon Forest (states of Mato Grosso do Sul and Mato Grosso), and Rio Grande do Sul (Riet-Correa et al. 1989, Salvador et al. 1998, Weiblen et al. 1989). In addition, BHV-5 has become the most frequently detected agent in a study with brain specimens which resulted negative at rabies diagnosis (Pinto et al. 2000).

This paper reports the isolation and characterisation of BHV-5 from the brain of a rabies infected calf.

\section{MATERIALS AND METHODS}

Case description. Brain and portions of the spinal cord of an one year old male calf presenting clinical signs of nervous impairment (lateral decubitus, hyperestesia and opisthotonous, with a course of 5 days) were submitted to the laboratory for histopathological and virological examinations.

Rabies diagnosis. Histopathological examination was performed on fragments of brain and spinal cord, which were fixed in $10 \%$ phosphate buffered formalin, processed and stained with hematoxylin-eosin (HE) following routine procedures (Luna 1968). Rabies diagnosis was carrried out by a standard direct fluorescent antibody test (DFAT; Dean et al. 1996) on nervous tissues, followed by the mouse inoculation test (Koprowski 1996).

Virus isolation. Suspensions of approximately $10 \%$ of brain fragments were prepared in Eagle's minimal essential medium (MEM) supplemented with $100 \mathrm{mg} / \mathrm{ml}$ enrofloxacin (MEM 10xAB). The inoculum was clarified by centrifugation at $1500 \mathrm{x} g$ for 15 minutes and the supernatant inoculated onto MDBK (Madin Darby bovine kidney, ATCC CCL-22) cells. After $1 \mathrm{~h}$ for adsorption at $37^{\circ} \mathrm{C}$, the inoculum was removed, cells washed three times with MEM 10xAB and overlaid with the same medium. Cells were monitored daily for cytopathic effect (CPE). In order to ensure that rabies virus was not present in the passaged material, after six passages in cell cultures cells were frozen and thawed, clarified by centrifugation and the supernantant inoculated into mice as above.

Antigenic and genomic characterization. The BHV-5 isolate (named EVI 340/96) was tested with a panel of monoclonal antibodies capable of distinguishing BHV-1 from BHV-5 in immunoperoxidase monolayer assays as described (Silva et al. 1996, Roehe et al. 1997, Almeida et al. 1998). Viral DNA was extracted from the virus isolate, as well as from control BHV-5 strains (V175 and N569; Souza et al. 2002) as described by Van Oirschot et al. (1995) and submitted to restriction endonuclease analysis (REA; Engels et al. 1986). Restriction enzyme digestion with BstEII was performed under the conditions recommended by the manufacturer (BRL) and the DNA fragments separated by electrophoresis on a 0.5 per cent agarose gel. A ? HindIII DNA ladder (BRL) was included as a DNA size marker. After electrophoresis, the gel was stained with ethidium bromide as recommended (Sambrook et al. 1989) and photographed under ultraviolet light.

\section{RESULTS}

Histopathological findings. Histopathological examination revealed moderate mielitis, mild meningoencephalitis with perivascular mononuclear cell cuffing in several areas of cerebral cortex and spinal cord, as well as a few cortical neurons surrounded by glial cells and mild meningitis. A large
Table 1. Monoclonal antibody (Mab) analysis of isolate EVI 340/96 and other bovine herpesviruses

\begin{tabular}{lccccc}
\hline \multirow{2}{*}{ Viruses } & \multicolumn{5}{c}{ Mabs $^{\mathrm{a}}$} \\
\cline { 2 - 6 } & Type & BD10 & 5A5 & 7F12 & 11 H6 \\
\hline EVI 340/96 & BHV-5 & + & - & - & - \\
N569 & “ & + & - & - & - \\
A663 & " & + & - & - & - \\
Cooper & BHV-1 & - & + & + & + \\
Iowa & " & - & + & + & + \\
Oxford & " & - & + & + & +
\end{tabular}

aMabs: monoclonal antibodies; "+" refers to positive reaction at immunoperoxidase; “- " refers to negative reactions. Other bovine herpesviruses were included for comparison only. Sources of BHV-5 strains "N569", "A663" and BHV-1 "Cooper", "Iowa" e "Oxford" described in Souza et al., (2002).

number of Negri inclusion bodies was observed in the Purkinje cells of cerebellum.

Rabies diagnosis. Examination of distinct regions of the brain (Amon's horn, frontal and parietal cortices and cerebellum) with rabies DFAT revealed the presence of rabies virus antigens. Mice inoculated with a $10 \%$ brain tissue suspension died within ten days days after inoculation. Brains of dead mice were again submitted to DFAT and the presence of rabies virus antigen was confirmed.

Virus isolations. A cytopathic effect (CPE) typical of lytic herpesviruses, was observed on MDBK cells at around 3 after

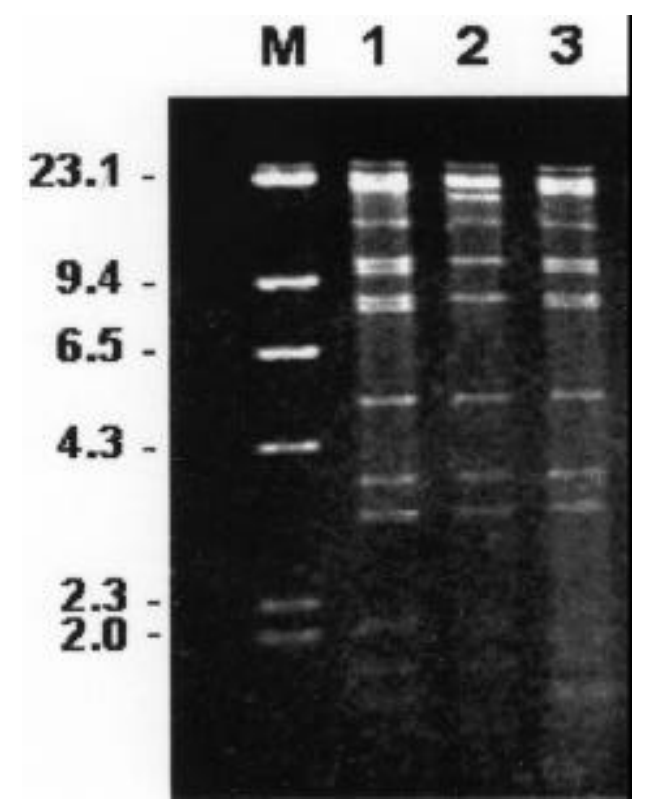

Fig. 1. Restriction enzyme (BstEII) analysis of BHV-5. Lane 1: BHV-5 "b" strain N569; lane 2: BHV-5.a strain A663; lane 3: BHV-5 "b" isolate EVI340/95; "M": Lambda/ HindIII DNA marker. Numbers in kilobases. Restriction fragments smaller than $2.3 \mathrm{~kb}$ were similar in the three preparations (although not clearly visible in the picture). 
inoculation. CPE was essentially characterized by focal areas of cell destruction, with accumulation of cells in the perimeter of roughly circular foci of cell dettachment from the monolayer. At the perimeter of the foci, ballooning of cell citoplasm, formation of sincytia with some extended cells forming long filaments. The virus isolate was named EVI 340/96, and was then further cultured on MDBK cells. No evidence for the presence of rabies virus antigens were detected in any of the stages of the in vitro subculturing. When the cell culture passaged virus titres reached $10^{8.0}$ $50 \%$ tissue culture infective doses per $50 \mathrm{ml}\left(\mathrm{TCID}_{50}\right), 30 \mathrm{ml}$ of the virus suspension were inoculated intracerebrally into weaned mice as above, and no deaths were observed up to 21 days of observation.

Antigenic and genomic characteri zation. The antigenic profile of the 340/96 isolate was similar to that displayed by the majority of the BHV-5 strains isolated in Brazil, as shown previously (Souza et al. 2002). REA on the viral genome confirmed that the profile evidenced with EVI 340/96 DNA is the same displayed by other known BHV-5 strains (Figure 1).

\section{DISCUSSION}

Rabies has long been recognised as a major cause of encephalitis in cattle in South America. Apart from its fatal outcome, the disease is a zoonosis, what tends to make of a positive rabies diagnosis the endpoint of any other diagnostic attempts. Thus, in most rabies laboratories, specimens with a negative diagnosis for rabies end up with no definitive diagnosis established. However, in recent years, studies in search for other possible pathogens in rabies-negative specimens have led to the detection BHV-5 in a considerable number of such samples (Salvador et al. 1998, Pinto et al. 2000). This virus has followed a rather different evolutionary pathway, where infections usually do not lead to the host's death, but rather establish a form of coexistence, with the establishment of latent infections (Turin et al. 1999). In analogy with a number of other herpesviruses (Roizman et al. 1992), including some human pathogens (Tang et al. 1997), cattle that actually die from BHV-5 encephalitis are probably only a fraction of animals who were actually infected with the virus. Moreover, some of these animals might eventually become infected with rabies virus. In the present study, a mixed infection rabies/BHV-5 was reported. Among the possibilities that might have led to the identification of this mixed infection, some must be commented here. It is possible that BHV-5 was present in a latent form in the brain tissue of the calf, and was reactivated after the virus isolation procedure. Although possible, this hypothesis seems unlikely, since virus reactivation from the usual site of latency - the trigeminal ganglia - is a somewhat cumbersome procedure that requires cocultivation of cells from the ganglia or ganglionic explant cultures (Osório 1998). Here, the procedure for virus isolation followed usual procedures and did not include explant cultures, thus favoring the multiplication of herpesviruses undergoing a lytic, not a latent, cycle of multiplication. Although it would be interesting to proceed to cocultivation/ explant cultures, in this case this was not possible since the available specimen had already been frozen by the time it arrived at the virology laboratory, thus compromising such attepmts in view of cell lysis. Another possibility is that BHV- 5 might have been reactivated by rabies. It has for long been known that herpesviruses tend to be reactivated from latency after stressing situations, including infections by other agents (Osório 1998, Tikoo et al. 1995).

Although the isolation of BHV-5 from such specimens does not add to the knowledge of the pathogenetic mechanisms that led to the calf's death, here we describe the isolation of BHV-5 from a confirmed case of rabies in a calf. It was not possible to determine whether BHV-5 played any active role in the outcome of such infection. Nevertheless, this is the first report of a mixed rabies/BHV-5 infection in calves. Mixed infections involving rabies virus and other agents have not, to the knowledge of the authors, been reported before. However, some herpesviruses like human cytomegalovirus, Epstein-Barr virus, herpes simplex virus (HHV-1) and human herpesvirus 6 (HHV-6) are occasionally found infecting simultaneously the human central nervous system, along with a number of different pathogens, including other herpesviruses (Waner 1994, Tang et al. 1997), influenza A virus (Studahl et al. 1994) and human immunodeficiency virus (Arribas et al. 1995, Cinque et al. 1992). Whether they cause direct tissue damage, induce immunossupression, or somehow influence the outcome of other infections remains unknown (Tang et al. 1997). Herpesviruses have been demonstrated to induce a release of interleukin-6 (IL-6), thereby disturbing immune homeostasis (Gosselin et al. 1992). Either BHV-5 or rabies virus might exert some similar effect on IL-6 release, thus adding to immunossupression.

\section{REFERENCES}

Almeida R.S., Melo, S.V., Silva T.C., Oliveira L.G., Lemos R.A. \& Roehe P.M.1998. Produção de anticorpos monoclonais contra o herpesvírus da encefalite bovina (BHV-5). Pesq. Agropec. Gaúcha 4:67-72.

Arribas J.R., Clifford D.B., Fichtenbaum C.J., Roberts R.I., Powderly W.G. \& Storch G.A. 1995. Detection of Epstein-Barr virus DNA in cerebrospinal fluid for diagnosis of AIDS-related central nervous system lymphoma. J. Clin. Microbiol. 33:1580-1583.

Caserta M.T., Hall C.B., Schnabel K., McIntyre K., Long C., Costanzo M., Dewhurst S., Insel R. \& Epstein L.G. 1994. Neuroinvasion and persistence of human herpesvirus 6 in children. J. Infect. Dis. 170:1586-1589.

Cinque P., Vago L., Brytting M., Castagna A., Accordini A., Sundqvist V.A., Zanchetta N., Monforte A.D., Wahren B. \& Lazzarin A. 1992. Cytomegalovirus infection in the central nervous system in patients with AIDS: diagnosis by DNA amplification from cerebrospinal fluid. J. Infect. Dis. 166:1408-1411.

Dean D.J., Abelseth M.K. \& Atanasiu P. 1996. The fluorescent antibody test, p. 88-93. In: Laboratory Techniques in Rabies. 4th ed. Meslin F.-X., Kaplan M.M. \& Koprowski H. (ed.) World Health Organization, Geneva.

Engels M., Giuliani C., Wild P., Beck T.M., Loepfe E. \& Wyler R. 1986. The genome of bovine herpesvirus 1 (BHV-1) strains exhibiting a neuropathogenic potential compared to know BHV-1 strains by restriction site map and cross hibridization. Virus Res. 6:57-73

French E.L.A. 1962. A specific virus encephalitis in calves: isolation and characterization of the causal agent. Aust. Vet. J. 38:216-221.

Gardiner M.R. \& Nairn M.E.1964. Meningoencephalitis of calves in Western Australia. Aust. Vet. J. 40:225-228.

Gosselin J., Flamand L., D’Addario M., Hiscott J., Stefanescu I., Ablashi D,V., 
Gallo R.C. \& Menezes J. 1992. Modulatory effects of Epstein-Barr, herpes simplex and human herpes- 6 viral infections and co-infections on cytokine synthesis. A comparative study. J. Immunol. 149: 181-187.

Johnston L.A.Y \& McGavin M.D. 1962. A viral meningoencephalitis in calves. Aust. Vet. J. 38:207-215.

Koprowski H. 1996. The mouse inoculation test, p. 80-86. In: Laboratory Techniques in Rabies. 4th ed. Meslin F.X, Kaplan M. M. \& Koprowski H. (ed.) World Health Organization, Geneva.

Luna L.G. 1968. Manual of histologic stainig methods of the Armed Forces Institute of Pathology $3^{\text {rd }}$ ed. American Registry of Pathology, McGraw-Hill, New York, p. 32-37.

Osório F.A. 1998. Latency of Bovine herpesvirus-1. Anais do Simpósio Internacional de Herpesvírus Bovino (tipo1 e 5) e Vírus da Diarréia Viral Bovina, UFSM, Santa Maria, p.117-126.

Pinto A.M.V., Romijn P.C., Silva R.C.F., Silva T.C., Alfieri A.A., Martins L.L., Weiblen R., Roehe P.M., Portes S.A.R. \& Leite J.P.G. 2000. Isolation and identification of herpesviruses in brains of calves with negative rabies diagnosis. XI Encontro Nacional de Virologia, São Lourenço, MG, 25-29 Nov. Virus Reviews and Research 5 (Suppl. 1):122. (Resumo)

Riet-Correa E., Vidor T, Schild A.L. \& Méndez M.C. 1989. Meningoencefalite e necrose do córtex cerebral em bovinos causada por herpesvirus bovino-1. Pesq. Vet. Bras. 9:13-16.

Salvador S.C., Lemos R.A.A., Riet-Correa F., Roehe, P.M. \& Osório A.LR. 1998. Meningoencefalite em bovinos causada por herpesvirus bovino-5 no Mato Grosso do Sul e São Paulo. Pesq. Vet. Bras. 18: 76-83.

Sanches A.W.D., Langohr I.M., Stigger A.L. \& Barros C.S.L. 2000. Doenças do sistema nervoso central em bovinos no Sul do Brasil. Pesq. Vet. Bras. 20:113118.

Silva T.C., Roehe P.M., Nardi N.B. \& Oliveira L.G. 1996. Produção e caracteri- zação de anticorpos monoclonais contra o vírus da rinotraqueíte infecciosa bovina (BHV-1). Arq. Bras. Med.Vet. Zootec. 49:513-522

Souza V.F, Melo S.V., Esteves P.A., Schmidt C.S.R., Gonçalves D., Schaefer R., Silva T.C., Almeida R.S., Vicentini F.K., Franco A.C., Oliveira E.A.S., Spilki F.R., Weiblen R., Flores E.F., Lemos R.A., Alfieri A.A., Pituco E.M. \& Roehe P.M. 2002. Caracterização de herpesvírus bovinos tipos 1 (BHV-1) e 5 (BHV-5) com anticorpos monoclonais. Pesq. Vet. Bras. 22(1):13-18.

Roehe, P.M., Silva, T.C., Nardi, N.B., Oliveira, L.G. \& Rosa, J.C.A. (1997) Diferenciação entre os vírus da rinotraqueíte infecciosa bovina e herpesvírus da encefalite bovina com anticorpos monoclonais. Pesq. Vet. Bras. 17:41-44.

Roizman B., Desrosiers R.C., Fleckenstein B., Lopez C., Minson A.C. \& Studdert M.J. 1992. The family Herpesviridae: an update. Arch. Virol. 123:425-448.

Studahl M., Richsten A., Sandberg T., Elowson S., Herner S., Sall C. \& Bergstrom T. 1994. Cytomegalovirus infection of the CNS in non-compromised patients. Acta Neurol. Scand. 89:451-457.

Tang Y., Espy M.J., Persing D.H. \& Smith T.F. 1997. Molecular evidence and clinical significance of herpesvirus coinfection in the central nervous system. J. Clin. Microbiol. 35:2869-2872.

Tikoo S.K., Campos M. \& Babiuk L. 1985. Bovine herpesvirus 1 (BHV-1): biology, pathogenesis and control. Adv. Virus Res 45:191-223

Turin L., Russo S. \& Poli G. 1999. BHV-1: new molecular approaches to control a common and widespread infection. Molec. Med. 5:261-284

Van Oirschot J.T., Risejwijk F.A.M., Straver P.J., Ruuls R.C. Quak J. Davidse A., Westerbrink F., Gielkens A.L.J., Van Dijk J.E. \& Moerman A. 1995. The virulence and genotype of a bovine herpesvirus isolate from semen of a subclinically infected bull. Vet. Rec. 137:235-239.

Waner J.L. 1994. Mixed viral infections: detection and management. Clin. Microbiol. Rev. 7:143-151.

Weiblen R., Barros C.S.L. \& Canabarro T.E. 1989. Bovine encephalitis from IBR virus. Vet. Rec. 124:666-667. 